\title{
PENGATURAN ABORSI DALAM PERSPEKTIF PERUNDANG-UNDANGAN INDOENESIA
}

\author{
Cindy Oeliga Yensi Afita
}

\author{
Dosen pada Fakultas Hukum Universitas Muara Bungo \\ Chinyoeliga@gmail.com
}

\begin{abstract}
RINGKASAN
Dalam konteks KUHP aborsi sangat jelas dilarang dengan alasan apapun dan dalam keadaan apapun. Namun Undang-Undang Nomor 36 Tahun 2009 Tentang Kesehatan mengecualikan hal tersebut dengan alasan kedaruratan medis dan akibat korban perkosaan dan sebagai pelaksananya dibuatlah Peraturan Pemerintah Nomor 61 Tahun 2014 Tentang Kesehatan Reproduksi. Hal ini jelas bertentangan dengan KUHP serta Undang-Undang Nomor 39 Tahun 1999 Tentang Hak Asasi Manusia yang mengatakan bahwa setiap anak sejak dalam kandungan memiliki hak untuk hidup dan meningkatkan taraf hidupnya begitu pula sebaliknya dengan yang termaktub dalam Undang-Undang Nomor 35 Tahun 2014 Tentang Perubahan Atas Undang-Undang 23 Tahun 2003 Tentang Perlindungan Anak. Akibat hukum terhadap wanita dan dokter yang melakukan tindakan aborsi ialah dilindungi dan mendapat kekebalan hukum jika tindakan aborsi tersebut dilakukan berdasarkan ketentuan dan standar di dalam Undang-Undang. Akibat hukum yang ditimbulkan jika tetap diberlakukannya Undang-Undang Nomor 36 Tahun 2009 Tentang Kesehatan dan Peraturan Pemerintah Nomor 61 Tahun 2014 Tentang Kesehatan Reproduksi ialah akan terjadinya ketidakpastian hukum.
\end{abstract}

\section{Kata Kunci: Pengaturan, Aborsi, Peraturan Perundang-undangan}

Aborsi selalu menjadi perbincangan, baik dalam forum resmi maupun tidak resmi yang menyangkut bidang kedokteran, hukum maupun disiplin ilmu lain. Aborsi merupakan fenomena sosial yang semakin hari semakin memperihatinkan. Keperihatinan itu bukan tanpa alasan, karena sejauh ini perilaku pengguguran kandungan banyak menimbulkan efek negatif baik untuk diri pelaku maupun pada masyarakat luas. Hal ini disebabkan karena aborsi menyangkut norma moral serta hukum suatu kehidupan bangsa.

Dalam KUHP pun telah dijelaskan mengenai pelarangan secara tegas tentang aborsi yang di tuangkan dalam Pasal 346, 347, 348, 349 KUHP. Menurut ketentuan dalam Pasal 346, 347, 348, dan 349 KUHP abortus criminalis meliputi perbuatan-perbuatan sebagai berikut:

1. Menggugurkan

Kandungan (afdrijving van de vrucht atau vrucht afdrijving)

2. Membunuh Kandungan (de dood van vrucht veroorzaken atau vrucht doden). ${ }^{1}$

Menurut Pasal 194 UndangUndang Nomor 36 Tahun 2009 Tentang Kesehatan "Setiap orang yang dengan sengaja melakukan aborsi tidak sesuai dengan ketentuan sebagaimana dimaksud dalam Pasal 75 ayat (2) dipidana dengan pidana penjara paling lama 10 tahun dan denda paling banyak Rp 1 miliar."

\footnotetext{
${ }^{1}$ Musa Perdana Kusuma, Bab-Bab Tentang Kedokteran Forensik, Ghalia Indonesia, Jakarta, 1981, hal. 192.
} 
Menjalani kehamilan adalah suatu yang sangat diidam-idamkan oleh kebanyakan perempuan di seluruh dunia, namun ada juga wanita yang menjalani kehamilan bukan dijadikan sebagai anugerah tetapi sebagai cobaan ketika kehamilan yang tidak dikehendaki misalnya karena perkosaan.

Dalam KUHP perkosaan dijelaskan dalam Pasal 285 yang berbunyi: Barangsiapa dengan kekerasan atau ancaman kekerasan memaksa perempuan yang bukan isterinya bersetubuh dengan dia, dihukum, karena memperkosa, dengan hukuman penjara selama-lamanya dua belas tahun.

\section{Korban}

pemerkosaan

membutuhkan waktu lama untuk mengatasi pengalaman traumatis, bahkan ada yang tidak pernah kembali lagi ke keadaan normal seperti sebelumnya. ${ }^{2}$ Selain itu juga, hak-haknya sebagai wanita dirampas, korban juga harus menanggung akibat dari pemerkosaan tersebut seperti timbulnya dampak fisik, dampak seksual dan dampak psikis yang teramat berat terutama pada saat korban mengalami pergaulan kehidupan sosial di masyarakat. Dampak lebih lanjut akibat dari pemerkosaan secara seksual adalah menyebabkan korban pemerkosaan mengalami kehamilan yang tidak dikehendaki. $^{3}$

Banyak pendapat mengenai norma baik itu norma kesopanan,

\footnotetext{
${ }^{2} \mathrm{G}$ Widiartana, Viktimologi Perspektif Korban Dalam Penanggulangan Kejahatan, Universitas Atma Jaya Yogyakarta, Yogyakarta, 2009, hal. 64

${ }^{3}$ Agato, Perlindungan Hukum Bagi Korban Pemerkosaan Yang Melakukan Aborsi, Jurnal Pada Universitas Atmajaya, Yogyakarta, 2014, hal. 1.
}

kesusilaan dan lain-lain. Soebakti bahwa:

hukum itu terdiri dari norma kesopanan, norma kesusilaan dan norma hukum yang disebut dengan norma sosial. Norma sosial merupakan ketentuan-ketentuan umum yang berlaku sebagai pedoman bertingkah laku bagi individu dalam kehidupan sosial. Yang penting dan perlu diperhatikan dalam hal ini adalah kegiatan individu dalam kaitannya dengan kehidupan sosial yang memiliki norma sosial. ${ }^{4}$

Terlepas dari alasan apapun yang menyebabkan terjadinya kehamilan tersebut, aborsi dilakukan karena adanya kehamilan yang tidak diiinginkan. Hal ini dikarenakan aborsi yang terjadi dewasa ini sudah menjadi hal yang aktual dan peristiwanya dapat terjadi dimana-mana dan bisa saja dilakukan oleh berbagai kalangan, apakah hal itu dilakukan oleh remaja yang terlibat pergaulan bebas ataupun para orang dewasa yang tidak mau dibebani tanggung jawab dan tidak menginginkan kelahiran bayi ke dunia ini. Kelahiran anak yang seharusnya dianggap sebagai suatu anugerah yang tidak terhingga dari Allah SWT, justru dianggap sebagai suatu beban yang kehadirannya tidak diinginkan. Ironis sekali memang, karena di satu sisi terdapat sekian banyak pasangan suami istri yang mendambakan kehadiran seorang anak selama bertahun-tahun masa perkawinan belum mendapatkannya, namun di sisi lain terdapat pasangan yang membuang anaknya bahkan janin yang masih dalam kandungan tanpa pertimbangan nurani kemanusiaan atau yang lebih dikenal dengan aborsi.

\footnotetext{
${ }^{4}$ Abdul Djamil, Psikolog Dalam Hukum, Armico, Jakarta, 1984, hal. 118.
} 
Banyak kajian mengenai aborsi karena tidak hanya tersangkut pada hukum pidana dimana hukum pidana secara tegas melarang aborsi apapun alasanya. Kajian mengenai legalitas aborsi melibatkan banyak ranah seperti hukum dan hak asasi manusia, hukum islam, perlindungan anak, perlindungan perempuan, serta argumentasi sosial masyarakat yang berbeda tentang hal ini. Adapun fatwa MUI (Majelis Ulama Indonesia) Nomor 4 Tahun 2005 Tentang Aborsi adalah sebagai berikut:

Pendapat mengenai peranan hukum pidana, dikemukakan antara lain oleh Sudarto bahwa:

Hukum pidana berperan dalam usaha untuk mewujudkan peraturan yang baik sesuai dengan keadaan dan situasi pada suatu saat, dan sebagai kebijakan dari Negara melalui bedanbadan yang berwenang untuk menetapkan peraturan yang dikehendaki, yang diperkirakan bisa dipergunakan untuk mengekspresikan apa yang dikandung dalam masyarakat dan untuk apa yang dicita-citakan. ${ }^{5}$

Namun Undang-Undang Nomor 36 Tahun 2009 Tentang Kesehatan berisi aturan yang menyebutkan bahwa aborsi boleh dilakukan dengan alasan indikasi kedaruratan medis dan aborsi akibat korban perkosaan, hal ini dengan jelas mengenyampingkan KUHP yang dengan tegas melarang aborsi dengan alasan apapun. Kemudian UndangUndangNomor 36 Tahun 2009 Tentang Kesehatan mengeluarkan Peraturan Pemerintah Nomor 61 Tahun 2014 Tentang Kesehatan Reproduksi yang menambah alasan diperbolehkannya aborsi. Adapun isi Pasal 31 PP No. 61 Tahun 2014 Tentang Kesehatan Reproduksi:

\footnotetext{
${ }^{5}$ Sudarto, Hukum dan Hukum Pidana, Alumni, Bandung, 1981, hal. 159.
}

1. Tindakan aborsi hanya dapat dilakukan berdasarkan:

a. indikasi kedaruratan medis; atau

b. kehamilan akibat perkosaan

2. Tindakan aborsi akibat perkosaan sebagaimana dimaksudpada ayat (1) huruf b hanya dapat dilakukan apabila usia kehamilan paling lama berusia 40 (empat puluh) hari dihitung sejak hari pertama haid terakhir.

Selama puluhan tahun aborsi, telah menjadi permasalahan bagi perempuan karena menyangkut berbagai aspek kehidupan baik itu moral, hukum, politik dan agama. Kemungkinan terbesar timbulnya permasalahan tersebut berakar dari konflik keyakinan bahwa fetus memiliki hak untuk hidup dan para perempuan memiliki hak untuk menentukan nasibnya sendiri, dalam hal ini melakukan pengguguran kandungan.

Perkembangan konflik yang tidak kunjung mendapatkan titik temu mengakibatkan munculnya penganut paham pro-life yang berupaya mempertahankan kehidupan dan prochoice yang mendukung supaya perempuan mempunyai pilihan untuk menentukan sikap atas tubuhnya dalam hal ini aborsi.

Perdebatan mengenai aborsi di Indonesia akhir-akhir ini semakin ramai, karena dipicu oleh berbagai peristiwa yang mengguncang sendisendi kehidupan manusia. ${ }^{6}$ Kehidupan yang diberikan kepada setiap manusia merupakan Hak Asasi Manusia yang hanya boleh dicabut oleh pemberi kehidupantersebut. Berbicara mengenai

${ }^{6}$ https://dukunhukum.wordpress.com/2012/ 04/13/aborsi-dalam-kuhp-indonesiadan -uu-no-36tahun-2009/, diakses tanggal 13 Januari 2017, pukul 17:08 Wib. 
aborsi tentunya kita berbicara tentang kehidupan manusia karena aborsi erat kaitannya dengan wanita dan janin yang ada dalam kandungan wanita. ${ }^{7}$

Menurut Nila Djuwita F. Moelek menyatakan pendapatnya dalam konfrensi pers peningkatan mutu kesehatan mengatakan:

Upaya peningkatan kualitas hidup manusia di bidang kesehatan merupakan suatu usaha yang sangat luas dan menyeluruh, usaha tersebut meliputi peningkatan kesehatan masyarakat baik fisik maupun non fisik. Di dalam Sistem Kesehatan Nasional disebutkan bahwa kesehatan menyangkut semua segi kehidupan yang ruang lingkup dan jangkauannya sangat luas dan kompleks. ${ }^{8}$

Dari pengertian diatas, dapat dipahami bahwa pada dasarnya masalah kesehatan menyangkut semua segi kehidupan manusia. 9 Kesehatan merupakan hak asasi manusia yang ditujukan untuk meningkatkan kesadaran, kemauan, dan kemampuan hidup sehat bagi setiap orang dalam rangka mewujudkan derajat kesehatan yang optimal secara menyeluruh dan terpadu sebagai salah satu unsur kesejahteraan umum sebagaimana dimaksud dalam pembukaan UndangUndang Dasar Negara Republik Indonesia Tahun 1945. ${ }^{10}$

Hukum merupakan sarana mewujudkan hak-hak manusia dalam

${ }^{7}$ Achadiat Charisdiono, 2007, Dinamika

Etika Dan Hukum Kedokteran, Buku

Kedokteran, Jakarta,hal. 12.

${ }^{8}$ Nila Djuwita F, dalam Upaya

Meningkatkan Kesehatan Masyarakat,

Kompas.com, Jakarta, 2016, hal. 4.

${ }^{9}$ Bahder Johan Nasution, Hukum

Kesehatan, Rineka Cipta, Jakarta, 2005, hal. 1.

${ }^{10}$ Lihat Konsideran menimbang Undang-

Undang Nomor 29 Tahun 2004 Tentang Praktik Kedokteran.. memenuhi kebutuhannya. Hakikat hukum adalah perlindungan kepentingan manusia, termasuk dalam mewujudkan kesehatan. Hukum kesehatan eksistensinya masih relatif baru perkembangannya di Indonesia yang semula dikembangkan oleh Fred Ameln dan Alm. Oetama dalam bentuk ilmu kedokteran. Ruang lingkup hukum kesehatan antara lain:

1. Hukum medis;

2. Hukum keperawatan;

3. Hukum rumah sakit;

4. Hukum perlindungan

konsumen;

5. Hukum pencemaran

lingkungan;

6. Hukum keselamatan kerja;

7. dan peraturan-peraturan

lainnya yang ada kaitan langsung yang dapat mempengaruhi kesehatan manusia. ${ }^{11}$

Akan tetapi hukum yang diharapkan sebagai wujud kepastian perlindungan kehidupan bagi umat manusia, malah hukum pula yang mengatur dan menentukan keberlangsungan hidup seseorang.

Hal ini terkait dengan permasalahan aborsi. Negara pada prinsipnya melarang tindakan aborsi, tetapi pada realitanya pada beberapa kondisi medis aborsi merupakan satusatunya jalan yang harus dilakukan tenaga medis untuk menyelamatkan nyawa seorang ibu yang mengalami permasalahan kesehatan atau komplikasi yang serius pada saat kehamilan.

Pengaturan melalui sistem hukum inilah yang dimaksud dengan

11 J.Guwandi, Hukum Medik (Medical Law), Jakarta, Balai Penerbit FKUI, 2005, hal. 13, dalam Amir Ilyas ,Pertanggungjawaban Pidana Dokter dalam Malpraktik Medik di Rumah Sakit, Rangkan Education, Yogyakarta, 2014, hal. 2. 
legalisasi. Perdebatan legalisasi aborsi ini memiliki sudut pandang masingmasing. Terdapat 3 (tiga) pendapat tentang aborsi, yaitu:

1. Pandangan konservatif.

Pandangan ini menganggap bahwa aborsi tidak boleh dilakukan dalam keadaan apapun juga. Disini terdapat alasan-alasan keagamaan dan filosofis antara lain kesucian kehidupan, larangan untuk memusnahkan kehidupan manusia yang tidak bersalah dan ketakutan akan implikasi sosial yang liberal bagi orang lain yang tidak dapat membela diri seperti cacat dan para lanjut usia;

2. Pandangan liberal.

Pandangan ini menganggap aborsi itu boleh dalam kondisi tertentu. Disini aborsi dianggap sebagai keputusan moral, tetapi dapat dibenarkan kelangsungannya secara moral, antara lain kualitas janin, kesehatan fisik dan mental wanita, hak wanita atas integritas diri, kesejahteraan keluarga, pertimbangan karier dan keluarga berencana;

\section{Pandangan moderat.}

Pandangan ini menempatkan diri di posisi tengah yang mengakui kemungkinan legitimasi moral sebagai alasan di langsungkannya aborsi, tetapi tidak sedikitpun menafikkan adanya penderitaan dan rasa berat hati dari pihak ibu terhadap janin. Pandangan ini melihat janin dan wanita sebagai pemilik hak yang mengakui bahwa dalam upaya memecahkan konflik hak seperti itu mau tidak mau akan menyebabkan penderitaan dan rasa berat hati sebagai konsekuensi. ${ }^{12}$

\footnotetext{
${ }^{12}$ Pitono Soeparto, Etika dan Hukum di Bidang Kesehatan, Surabaya, Penerbit Komite Etik RSUD Dr. Soetomo, 2001, hal. 105.
}

Indonesia sebagai negara hukum yang menganut aliran hukum positif mengatur mengenai pengguguran dan pembunuhan kandungan (doodslag opeen ongeborn vrucht) dalam pasal 346,347, 348, dan 349 Kitab UndangUndang Hukum Pidana. Secara eksplisit, dapat ditarik kesimpulan bahwa pengguguran dan pembunuhan kandungan itu mutlak dilarang dan diancam pidana apabila dilakukan.

Mengenai tindakan aborsi ini, Undang-Undang Nomor 36 Tahun 2009 Tentang Kesehatan yang menggantikan Undang-Undang Nomor 23 Tahun 1992 Tentang Kesehatan pada prinsipnya sejalan dengan ketentuan pidana yang ada, yaitu melarang setiap orang untuk melakukan aborsi. Namun, dalam tataran bahwa negara harus melindungi warganya dalam hal ini perempuan yang melakukan aborsi berdasarkan indikasi kedaruratan medis dan akibat perkosaan, serta melindungi tenaga medis yang melakukannya.

$$
\text { Undang-undang Nomor } 36
$$

Tahun 2009 tentang Kesehatan membuka pengecualian untuk aborsi berdasarkan indikasi kedaruratan medis dan kehamilan akibat perkosaan. Dalam Pasal 75 ayat 2 UU No. 36 Tahun 2009 disebutkan bahwa aborsi dapat dilakukan dalam kondisi tertentu yautu indikasi kedaruratan medis dan perkosaan. Pada ayat 4 Undang-Undang tersebut menyatakan bahwa ketentuan lebih lanjut mengenai indikasi kedaruratan medis dan perkosaan sebagai syarat pengecualian dilakukannya aborsi diatur lebih lanjut dengan Peraturan Pemerintah. Peraturan Pemerintah yang dimaksud yaitu Peraturan Pemerinah Nomor 61 Tahun 2014 tentang Kesehatan Reproduksi. Dijelaskan bahwa dengan alasan korban perkosaan maka 
seseorang dapat dengan legal melakukan aborsi.

Aborsi yang dilegalkan akibat indikasi medis dan akibat korban perkosaan membuat dilemma tersendiri. Banyak masyarakat dan lembaga tetentu yang kontra akan pengesahan Peraturan Pemerintah Nomor 61 Tahun 2014 Tentang Kesehatan Reproduksi. Bagi sebagian masyarakat yang berfikiran kontra terhadap Peraturan Pemerintah ini hal ini akan menjadi masalah baru dan pemicu semakin maraknya pergaulan bebas dan aborsi di Indonesia.

\section{Perumusan Masalah}

Berdasarkan uraian pada latar belakang tersebut di atas, maka dirumuskan beberapa masalah pokok yang akan diteliti adalah sebagai berikut:

1. Bagaimana pengaturan aborsi akibat korban perkosaan dalam perspektif perundang-undangan?

2. Apa akibat hukum terhadap penetapan aturan aborsi akibat korban perkosaan?

Apabila ditinjau dari perspektif hukum positif Indonesia penghilangan hak hidup dapat diancam dengan hukuman yang berat sebagaimana yang diatur dalam KUHP, seperti pembunuhan yang direncanakan terlebih dahulu, atau karena kelalaian yang menyebabkan matinya seseorang. Selain itu juga disinggung hak reproduksi yang didasarkan pada pengakuan hak asasi manusia (HAM) bagi setiap pasangan atau individu untuk menentukan secara bebas dan bertanggung jawab mengenai jumlah anak, penjarakan anak, dan menentukan kelahiran anak mereka. ${ }^{13}$

\footnotetext{
${ }^{13}$ Mia Amalia, "Kekerasan Perempuan Dalm Perspektif Hukum Dan Sosiokultural”, Jurnal Wawasan Yuridika, Volume 25, Nomor 2,
}

Aborsi menjadi salah satu masalah yang cukup serius dan perlu penanganan segera, dan dalam lapangan ilmu kedokteran pun telah cukup meresahkan, sehingga lahirlah pemahaman bahwa aborsi merupakan desakan berbagai pihak agar "masalah saat kapan dimulainya sebuah kehidupan dan saat itu pula kehidupan itu dianggap tidak ada, dapat diagendakan secepatnya".14

Aborsi atau abortus secara buatan atau juga disebut terminasi kehamilan yang mempunyai dua jenis, yakni bersifat legal (abortus provocatus criminalis) dan yang bersifat legal (abortus provocatus therapeuticus). ${ }^{15}$ Masalah aborsi saat ini sudah bukan merupakan rahasia lagi untuk dibicarakan, akrena aborsi sudah menjadi hal yang actual darn peristiwanya sudah terjadi dimanamana dan dilakukan oleh siapa saja, bahkan telah menjadikan anak yang akan dilahirkan menjadi korban. aborsi sudah perlu mendapat perhatian melalui pengaturan yang lebih bijak untuk menghindari praktik aborsi yang tidak aman dan pemenuhan hak reproduksi perempuan maupun hak asasi perempuan dan anak (janin).

Legalisasi aborsi perlu diperhatiakn lebih bijak tetapi bukan dalam pengertian memberikan liberalisasi aborsi. Meskipun aborsi secara hukum pidana terlarang, tetapi

Universitas Suryakencana, Cianjur Jawa Barat, 2017, Hal. 401.

${ }^{14}$ Waluyadi, Ilmu Kedokteran Kehakiman

Dalam Perspektif Peradilan dan Aspek Hukum

Praktik Kedokteran, Djambatan, Jakarta, 2007, Hal. 77.

\footnotetext{
${ }^{15}$ Cucu Sholihah, "Kajian Terhadap Tindakan Atas Jiwa Dan Bukan Jiwa (Aborsi) Menurut Hukum Pidana Islam dan Hukum Kesehatan”, Jurnal Hukum Fakultas Hukum Universitas Suryakencana, Cianjur Jawa Barat, Volume 5, 2009, Hal. 11.
} 
kenyataannya aborsi masih banyak dilakukan oleh perempuan sengan berbagai alasan disebabkan peraturan dan hukum yang ada kurang akomodatif terhadap alasan-alasan yang memaksa perempuan melakukan tindakan aborsi.

Sebagaimana dimaksud dalam pembukaan Undang-Undang Dasar 1945, menegaskan tentang menciptakan suatu kesejahteraan umum dalam negara (welfare state). Untuk kesejahteraa umum tersebut, mutlak dibutuhkan saran ketertiban sosial, yang merujuk pada upaya menciptakan aman, tertib dan damai, yang salah satunya melalui sarana hukum (terutama penegakan hukum). Hukum yang berfungsi imperative sebagai sarana control sosial diwujudkan dalam sanksin-sanksinya, yang berkorelasi antara penerapan hukum sebagai kebijakan hukum, khususnya hukum pidana yang dilakukan melalui kebijakan keriminal (criminal policy) dan kebijakan sosial (social policy). Selain itu Undang-Undang Dasar 1945 Amandemen kedua Pasal 28A-J telah memberikan jaminan atas Hak Asasi Manusia (HAM), yang kemudian dipertegas dalam Undang-Undang Nomor 39 Tahun 1999 Tentang Hak Asasi Manusia (HAM). ${ }^{16}$

$$
\text { Hukum pada umumnya }
$$
diartikan sebagai keseluruhan kumpulan-kumpulan peraturanperaturan tertulis atau kaidah-kaidah dalam suatu masyarakat sebagai susunan sosail, keseluruhan peraturan tingkah lau yang berlaku dalam suatu kehidupan bersama yang dapat dipaksakan pelaksanaannya dengan memberikan sanksi bila dilanggar. Tujuan pokok dari hukum ialah menciptakan suatu tatanan hidup dalam masyarakat yang tertib dan sejahtera di

\footnotetext{
${ }^{16}$ Yesmil Anwar, Kriminologi, Refika Aditama, Bandung, 2010, Hal. 178.
}

dalam keseimbangan-keseimbangan, utnuk terciptanya ketertiban di dalam masyarakat diharapkan kepentingan manusia akan terlindungi. Modernisasi menjadi proyek yang normative di negara-negara berkembang dan modernitas menjadi tujuan yang didambakan. Menurut Hegel, Marx dan teori kritis, terdapat sebuah penegasan yang lebih radikal dan total, setiap masyarakat manusia teriri dari atas makhluk-makhluk rasional dan dapat menentukan diri, 17

Dilihat dari segi hukum kedokteran pada dasarnya bertumpu pada hak-hak dasar manusia yang melekat sejak lahir. Dasar pertama adalah ha katas pemeliharaan kesehatan (the right to health care) dan hak kedua adalah hak untuk menentukan nasib sendiri (the right to self determination). Dari kedua unsur itulah hukum kedokteran berdiri, karena apabila kita membahas hukum kedokteran tidak mungkin kita melupakan kaitan antara hak manusia dan kesehatan. ${ }^{18}$

Hak asas manusia merupakan hak dasar yang secara berarti melekat pada diri manusi bersifat universal dan langgeng. Oleh karena itu, hak asasi manusia harus dilindungi, dihormati, dipertahankan dan tidak boleh diabaikan, dikurangi atau dirampas oleh siapapun.

Hak untuk hidup adalah salah satu hak asasi manusia yang dicantumkan dalam konstitusi negara sebagaimana dijelaksan dalam Pasal 28 (a) Undang-Undang Dasar 1945 yang berbunyi "setiap orang berhak untuk hidup serta berhak mempertahankan hidup dan kehidupannya". Dengan hak

${ }^{17}$ Dedi Mulyadi, Internalisasi Nilai-Nilai Ideologi Pancasila, Refika Aditama, Bandung, 2014, Hal. 12.

${ }^{18}$ Moh. Hatta, Hukum Kesehatan dan Sengketa Medik, Liberty, Yogyakarta, 2013, Hal. 9. 
hidup itu negara akan menjaga dan melindungi hak hidup setiap warga negaranya, sehingga negara melalui alat negara penegak hukum akan bertindak apabila ada dan diketahui terjadi penghilangan hak hidup manusia, dan dalam ketentuan Pasal 34 UndangUndang Dasar Tahun 1945 negara mempunyai kewajiban untuk melindungi harkat dan martabat anak. Istilah aborsi sudah tidak asing algi bagi kita. Aborsi dilakukan oleh seorang wanita hamil, baik yang sudah menikah maupun belum. Banyak alasan mengapa wanita hamil melakukan aborsi, diantaranya karena tidak ingin memiliki anak, tidak mampu secara finansial untuk memenuhi kebutuhan si anak, atau karena hamil di luar nikah. Pandangan paradigma yang mengedepankan hak anak (pro life) dikedepankan oleh KUHP. Mereka yang melakukan aborsi bahwa ketika kandungan baru berumur tiga atau empat minggu belum terdapat kehidupan pada embrio.

Aborsi ada kaitannya dengan Hak Asasi Manusia (HAM) menurut Pasal 1 ayat (1) Undang-Undang Nomor 39 Tahun 1999 tentang Hak Asasi Manusia (HAM), HAM adalah seperangkat hak yang melekat pada hakikat dan keberadaan manusia sebagai makhluk tuhan yang maha kuasa dan merupakan anugerah-nya yang wajib dihormati, dijunjung tinggi dan dlindungi oleh negara, hukum dan pemerintah dan setiap orang demi kehormatan serta perlindungan harkat dan martabat manusia. Di dalam Pasal 9 Undang-Undang Nomor 39 Tahun 1999 ditegaskan sebagai berikut:

1. Setiap orang berhak untuk hidup, mempertahankan hidup, dan meningkatkan taraf kehidupannya;
2. Setiap orang berhak hidup tentram, aman, damai, bahgia, sejahtera lahir dan batin;

3. Setiap orang berhak atas lingkungan hidup yang baik dan sehat.

Dari penjelasan Pasal 9 UndangUndang Nomor 39 Tahun 1999 tantang Hak Asasi Manusia (HAM) dapat diatrik kesimpulan bahwa setiap orang berhak untuk hidup, mempertahankan hidup, dan meningkatkan taraf hidupnya. Tidak seorangpun dapat mengambil hak seseorang untuk hidup, mempertahankan hidup dan meningkatkan taraf hidupnya.

Hak anak di dalam UndangUndang Nomor 39 Tahun 1999 yang termaktub di dalam Bagian Kesepuluh Hak Anak yang berbunyi sebagai berikut:

\section{Pasal 52}

1. Setiap anak berhak atas perlindungan oleh orang tua, keluarga, masyarakat, dan negara;

2. Hak anak adalah hak asasi manusia dan untuk kepentingannya hak anak itu diakui dan dilindungi oleh hukum bahkan sejak dalam kandungan.

\section{Pasal 53}

1. Setiap anak sejak dalam kandungan, berhak untuk hidup, mempertahankan hidup, dan meningkatkan taraf hidupnya;

2. Setiap anak sejak kelahirannya, berhak atas suatu nama dan status kewarganegaraan.

Melalui penjelasan Pasal 52 dan 53 Undang-Undang Nomor 39 Tahun 1999 tantang Hak Asasi Manusia jelas terlihat bahwa anak memiliki hak untuk hidup, mempertahankan hiudp dan meingkatkan taraf hidupnya. Bahkan anak memiliki hak untuk hidup sejak dalam kandungan. Aborsi ialah upaya mematikan janin yang ada di dalam kandungan, dan hal ini bertentang dengan Pasal 52 dan 53 Undang-Undang 
Nomor 39 Tahun 1999 tantang Hak Asasi Manusia. ${ }^{19}$

Pendapat lain mengenai Hak Asasi Manusia (HAM) dikemukakan oleh Bahder Johan Nasution yang menjelaskan sebagai berikut:

Manusia diciptakan oleh Tuhan Yang Maha Esa dengan seperangkat hak yang menjamin derajatnya sebagai manusia. Hak-hak inilah yang kemudian disebut dengan hak asasi manusia, yaitu hak yang diperoleh sejak kelahirannya, sebagai manusia yang merupakan karunia sang pencipta. Hal ini dengan tegas dimuat dalam Pasal 1 butir 1 Undang-Undang Nomor 31 Tahun 1999 tentang Hak Asasi Manusia yang mendefinisikan hak asasi manusia sebagai seperangkat hak yang melekat pada hakikat keberadaan manusia sebagai makhluk Tuhan Yang Maha Esa dan merupakan anugerah-Nya yang wajib dihormati, dijunjung tinggi dan dilindungi oleh negara, hukum, pemerintah dan setiap orang demi kehormatan serta perlindungan harkat dan martabat manusia. ${ }^{20}$

Manusia bebas untuk bertindak dengan tidak terikat oleh sesuatu apapun. Keadaan manusia adalah keadaan yang sepenuhnya bebas mengatur tindakan yang dianggap pantas bagi dirinya sendiri tanpa harus bergantung pada kehendak dan kemauan orang lain. ${ }^{21}$

John locke berargumentasi bahwa semua individu dikarunia oleh alam hak inheren atas kehidupan, kebebasan dan harta yang merupakan milik mereka sendiri dan tidak dapat

\footnotetext{
${ }^{19}$ Pasal 52 dan 53 Undang-Undang Nomor 39 Tahun 1999 tantang Hak Asasi Manusia

${ }^{20}$ Bahder Johan Nasution, Negara Hukum Dan Hak Asasi Manusia, Mandar Maju, Bandung, 2014, Hal. 15.

${ }^{21}$ Basuki Ismail, Negara Hukum, Yayasan Badan Penerbit, Universitas Gajah Mada, Yogyakarta, 1993, Hal. 37.
}

dipindahkan atau dicabut oleh negara. Hak-hak tersebut sifatnya kodrati dalam arti:

1. Kodrat yang menciptakan dan mengilhami akal budi dan pendapat manusia;

2. Setiap orang dilahirkan dengan hak-hak kodrati tersebut;

3. Hak-hak kodrati itu dimiliki manusia dalam keadaan alamiah (state of nature) dan kemudian dibawanya dalam hidup bermasyarakat. ${ }^{22}$

Piagam Hak Asasi Manusia 9HAM) di Indonesia ditetapkan dengan Tap MPR Nomor XVII/MPR/1998. Piagam tersebut memuat berbagai hak asasi diantaranya sebagai berikut:

1. Hak Untuk Hidup;

2. Hak berkeluarga dan melanjutkan keturunan;

3. Hak mengembangkan diri;

4. Hak keadilan;

5. Hak kemerdekaan;

6. Hak atas kebebasan informasi;

7. Hak keamanan dan hak kesejahteraan;

8. Hak untuk melaksanakan kewajiban;

9. Hak perlindungan dan pemajuan terhadap hak asasi.

Dalam piagam Hak Asasi Manusia disebutkan bahwa manusia adalah makhluk pilihan Tuhan Yang Maaha Esa sebagai pengelola dan pemelihara alam di bumi untuk kesejahteraan umat manusia, yang melaksanakan tugasnya dengan penuh ketaqwaan dan tanggung jawab, oleh karena itu manusia dianugerahi hak asasi dan dibebani kewajiban untuk menjamin keberadaan, harkat, martabat, dan kemuliaan dirinya serta kehormatan lingkungannya. Bahwa hak

\footnotetext{
${ }^{22}$ Scott Davidson, Human Rights, Open University Press, Buckingham, 1993, Hal. 37.
} 
asasi adalah hak-hak dasar yang melekat pada diri manusia secara kodrati, universal dan langgeng sebagai anugerah Tuhan Yang Maha Esa, meliputi hak untuk hidup, hak berkeluarga untuk melanjutkan keturunan, hak mengembangkan diri, hak keadilan, hak kemerdekaan, hak keamanan, dan hak kesejahteraan yang berfungsi menajga integritas keberadaannya oleh karen itu tidak boleh diabaikan atau dirampas oleh siapapun.

Pada hakikatnya anak di dalam kandungan termasuk dalam domain perlindungan anak. Hal ini menjadi landasan dari dilarangnya praktik aborsi illegal. Meski sudah diatur UndangUndang, namum faktanya praktik aborsi illegal baik atas nama kedokteran, bidan, tenaga kesehatan dan perdukunan masih marak dan banyak ditemukan. Tahun lalu, Badan Kependudukan dan Keluarga Berencana Nasional (BKKBN) melakukan survey demografi dan kesehatan Indonesia. Hasilnya, terjadi peningkatan praktik aborsi di kalangan remaja putri jika dibandingkan dengan tahun sebelumnya. Kebanyakan pelaku aborsi tinggal di wilayah perkotaan dengan rentang usia 15-19 tahun. Alasan aborsi karena kehamilan yang tidak diinginkan, hal ini tentu sangat miris jika ditinjau dari perspektif perlindungan anak.

Sementara itu, dalam ketentuan Dan Undang-Undang Nomor 35 Tahun 2014 Tentang Perubahan Atas UndangUndang Nomor 23 Tahun 2002 Tentang Perlindungan Anak, dalam BAB I Ketentuan Umum Pasal 1 angka (1) Undang-Undang Nomor 35 Tahun 2014 Tentang Perubahan Atas UndangUndang Nomor 23 Tahun 2002 Tentang Perlindungan Anak "anak adalah seseorang yang yang belum berusia 18 (delapan belas) tahun, termasuk anak yang masih di dalam kandungan". ${ }^{23}$

Seorang anak memiliki hak hidup sejak ditiupkan ruh di dalam rahim hingga lahir ke dunia ini. hak hidup ini tidak boleh dirampas dengan alasan apapun karena menjadi anugerah dari Tuhan Yang Maha Esa dan anak yang masih di dalam kandungan secara hukum juga harus dilindungi oleh negara.

Ketentuan sebagaimana disebutkan di atas tersebut memberikan kewenangan tidak hanya kepada negara saja, tetapi juga kepada setiap orang untuk dapat membantu agar seorang anak tidak menjadi korban kekerasan, baik fisik, mental maupun seksual, dan menjaga anak (termasuk yang masih di dalam kandungan). Tetapi tidak disebutkan anak yang bagaimana, latar belakang terjadi konsepsinya, sudah bernyawa atau belum sehingga perlu penegasan yang lebih terinci lagi secara hukum.

Dalam perspektif Pasal 1 angka (1) Undang-Undang Nomor 35 Tahun 2014 Tentang Perubahan Atas UndangUndang Nomor 23 Tahun 2002 Tentang Perlindungan Anak menyebutkan anak ialah seseorang yang berusia di bawah 18 tahun, termasuk yang masih dalam kandungan. Artinya di sini aborsi tidak dibenarkan karena mengabaikan hak hidup anak. Selain merupakan tindak pidana, aborsi juga merupakan pelanggaran terhadap hak asasi. Terlebih otoritas mencabut hak hidup hanya pada Tuhan.

Undang-Undang Nomor 35 Tahun 2014 Tentang Perubahan Atas Undang-Undang Nomor 23 Tahun 2002 Tentang Perlindungan Anak, telah

\footnotetext{
${ }^{23}$ Pasal 1 angka (1) Undang-Undang Nomor 35 Tahun 2014 Tentang Perubahan Atas Undang-Undang Nomor 23 Tahun 2002 Tentang Perlindungan Anak.
} 
memberi kepastian hukum mengenai konsep perlindungan anak yang masih berada di bawah 18 (delapan belas) atau belum kawin dan juga terhadap anak yang masih dalam kandungan. Perlindungan anak adalah segala kegiatan untuk menjamin, melindungi anak dari dan hak-haknya agar dapat

\section{DAFTAR PUSTAKA}

A. BUKU

B.

Jurnal Pada Universitas Atmajaya,

A.Ubaedillah \& Abdul Rozak, Pancasila, Yogyakarta, 2014.

Demokrasi, HAM, dan MasyarakaAgus Purwadianto, Perkosaan Sebagai Madani, Kencana, Jakarta, 2014.

Abdul Fadil Mohsin Ebrahim, Isu-Isu Biomedis Dalam Perspektif Islam, Aborsi, Kontrasepsi dan Mengatasi Kemandulan (Terjemahan Sari Meutia)Andi Bandung, 1998.

hidup, tumbuh dan berkembang secara optimal sesuai dengan harkat dan martabat kemanusiaan. Serta mendapat perlindungan dari kekerasan dan diskriminasi. Hak-hak anak untuk tumbuh dan berkembang kini telah dirampas sejak dalam kandungan.

Pelanggaran HAM (Kajian Filosofis Metodologi Pembuktian Hukum), Disertasi, Universitas Guna Darma, Jakarta, 2003.

Hamzah, Asas-Asas Hukum Pidana, Rineka Cipta, Jakarta, 2008.

Abdul Jamil, Psikolog Dalam Hukum Arief Mansjoer, Perlindungan Korban Aborsi, Armico, Jakarta, 1984.

PT. Mabhakti, JAKARTA, 1997.

Abdul Wahid dan Muhammad Irfan Arif Budjianto, Kejahatan Seks Dan Aspek Perlindungan Terhadap Korban Kekerasan Seksual (Advokasi Atas Hak Asasi Perempuan), Refika Aditama, Bandung, 2011. Medik Legal Gangguan Psikoseksual, Pustaka Kalam, Medan, 1982.

Bahder Johan Nasution, Hukum Kesehatan, Rineka Cipta, Jakarta, 2005.

Abrori, Di Simpang Jalan Aborsi, Gigih Pustaka Mandiri, Semarang, 2014. Bahder Johan Nasution, Metode Penelitian

Achadiat Charisdiono, Dinamika Etika Dan Hukum, Mandar Maju, Bandung, 2016.

Hukum Kedokteran, Buku Kedokteraß Bahder Johan Nasution, Negara Hukum dan Jakarta, 2007.

Hak Asasi Manusia, Mandar Maju,

Achmad Ali, Menguak Tabir Hukum (Suatu Bandung, 2014.

Kajian Filosofis dan Sosiologis Barda Nawawie Arief, Bunga Rampai Gunung Agung, Jakarta, 2002. Kebijakan Hukum Pidana, PT. Citra

Adami Chazawi, Kejahatan Terhadap Tubuh Aditya Bakti, Bandung, 1996.

Dan Nyawa, Raja Grafindo Persadzecep Triwibowo, Etika dan Hukum Jakarta, 2002. Kesehatan, Nuha Medika, Yogyakarta,

Agato, Perlindungan Hukum Bagi Korban 2014.

Pemerkosaan Yang Melakukan Aborsi, 
Darwint Prints, Dalam Sosialisasi daKoes Iritanto, Kesehatan Reproduksi Diseminasi Penegakan Hak Asasi (Reproductive Health) Teori dan Manusia, Jakarta, 2001. Praktikum, CV. Alfabeta, Bandung, 2015.

Dicky Azwan, Bahan Ajar Hukum Pidana,

Departemen Pendidikan NasionđKusmaryanto, Kontroversi Aborsi, PT. Fakultas Hukum Universitas Jambi, Grasindo, Jakarta, 2002. Jambi, 2015.

Leden Marpaung, Kejahatan Terhadap

Dikdik M. Arief Manur dan Elisatris Gultom, Kesusilaan Dan Masalah Prevensinya, Urgensi Perlindungan Korban Sinar Grafika, Jakarta, 2004.

Kejahatan Antara Norma Dan Realita,

Raja Grafindo Persada, Jakarta, 2007. Leden Marpaung, Unsur-Unsur Perbuatan Yang Dapat Dihukum (Delik), Sinar

Dominikus Rato, Filsafat Hukum Mencari Grafika, Jakarta, 1991.

dan Memahami Hukum, Laksbang

Pressindo, Yogyakarta, 2010. Lilien Eka Chandra, Dalam Kasus Aborsi Indonesia, Balai Pustaka, Jakarta, 2006.

Fatwa MUI (Majelis Ulama Indonesia)

Nomor 4 Tahun 2005 Tentang Aborsi. Mien Rukmini, Laporan Akhir Penelitian Tentang Aspek Hukum Pelaksanaan

G Widiartana, Viktimologi Perspektif Korban Dalam Penanggulangan Kejahatan, Universitas Atma Jaya Yogyakarta, Aborsi Akibat Perkosaan, BPHN Yogyakarta, 2009. Departemen Kehakiman dan HAM RI, Jakarta, 2002.

Moeljatno, Asas-asas Hukum Pidana, Rineka

Hariyanto, Dampak Psikologis Korban Cipta, Jakarta, 2015.

Tindak Pidana Perkosaan Terhadap

Wanita, Pusat Studi Wanita GajaMoh. Mahfud MD, Politik Hukum Di Mada, Yogyakarta, 1997. Indonesia, Edisi Revisi, Rajawali Pers, 2009.

J.Guwandi, Hukum Medik (Medical Law),

Jakarta, Balai Penerbit FKUI, 200\$Musa Perdana Kusuma, Bab-Bab Tentang dalam Amir Ilyas , Kedokteran Forensik, Ghalia Indonesia, Pertanggungjawaban Pidana Dokter Jakarta, 1981.

dalam Malpraktik Medik di Rumah

Sakit, Rangkan Education, Yogyakarta,ila Djuwita F, Dalam Upaya Meningkatkan 2014.

Kesehatan Masyarakat, Kompas, Jakarta, 2016.

Kartini Kartono, Patologi Sosial, Raja

Grafindo, Jakarta, 2001. Nitibaskara, Catatan Kriminalitas, Jayabaya Univerity Press, Jakarta, 1999.

Kitab Undang-Undang Hukum Pidana, Moeljatno, Bumi Aksara, Cet:26,----------, Ketika Kejahatan Berdaulat, Bandung, 2006. Peradaban, Jakarta, 2001. 


\section{----------, Perlindungan Hukum}

Pelaksanaan Aborsi Bagi Perempuaßuryono Eko Tama, Hukum Kesehatan Dan Korban Perkosaan, Prambanan Agung Penjelasannya, Bumi Aksara, Jakarta, Law Firm, Jakarta, 2006. 2001.
P.A.F Lamintang, Pembahasan KUHATim Prima Pena, Kamus Besar Bahasa Menurut Ilmu Pengetahuan Hukum Indonesia, Gitamedja Press, Pidana Dan Yurisprudensi, Edisi 2, Yogyakarta, 2008.

Cetakan I, Sinar Grafika, Jakarta, 2010.

Waluyadi, Ilmu Kedokteran Kehakiman dalam Perspektif Peradilan dan

Pitono Soeparto, Etika dan Hukum di Bidang AspekHukum Praktik Kedokteran, Kesehatan, Surabaya, Penerbit Komite Etik RSUD Dr. Soetomo, 2001. Djambatan, Jakarta, 2005.

Wiryono Prodjodikoro, Tindak-tindak Pidana R. Atang Ranoemihardja, Ilmu Kedokteran Tertentu di Indonesia, Eresco, Bandung, Kehakiman, (Forensic Sience), Tarsito, Bandung, 1991. 1986.

Zainal Abidin, Pengantar Hukum Pidana,

R. Soesilo, KUHP Serta Komentar- Sinar Grafika, Jakarta, 1987.

Komentarnya Lengkap Pasal Demi

Pasal, Politea, Tanpa Tahun, Bogor.

C. JURNAL

Agato, "Perlindungan Hukum Bagi Korban

Rena Yulia, Viktimologi: Perlindungan Perkosaan Yang Melakukan Aborsi”, Hukum Terhadap Korban Kejahatan, 2014.

Graha Ilmu, Yogyakarta, $2010 . \quad$ http://ejournal.udayana.ac.id/index.php/jj/artic

Senoadji, Hukum Kedokteran (Medical Law) Aspek Hukum Pidana dan Perdata le/viewfile/6754/Ty/94, diakses tanggal 15 September 2017.

Dalam Simposium Hukum Kedokterar Suryono Ekotama, ST, “Abortus Provocatus BPHN Departemen Kehakiman, Jakarta, 1983.

Bagi Korban Perkosaan Perspektif Viktimologi, Kriminologi dan Hukum Pidana", Universitas Atmajaya

Soerjono Soekanto dan Sri Mahmudji, Yogyakarta, 2001. Penelitian Hukum Normatif, Suatu Tinjauan Singkat, Raja Grafindo Persada, Jakarta, 2003.

Soerjono Soekanto, Pengantar Ilmu Hukum, UI Press, Jakarta, 1986.

Dellya Suryana, SH, "Legalisasi Aborsi

Sudarto, Hukum dan Hukum Pidana, Alumni, Bandung, 1981.

Suparmono, Surat Dakwaan Dan Putusan Hakim Yang Batal Demi Hukum, Jambatan, Jakarta, 1991.

Menurut Hukum Positif Indonesia", Hukum Pidana, Universitas Airlangga, 2008.

http://ejournal.airlangga..ac.id/index.ph p/jj/article/viewfile/6765/Vr/41, diakses tanggal 31 Oktober 2017. $\mathrm{p} / \mathrm{Js} /$ article/view/14, diakses tanggal 17 September 2017. 
Annete Anastahsia Napitupulu,

"Pembaharuan Hukum PidanXia Amalia, "Kekerasan Perempuan Dalam Terhadap Tindak Pidana Aborsi di Perspektif Hukum Dan Sosialkultural", Indonesia", Jurnal Hukum Fakultas Jurnal Hukum Wawasan Yuridika, Hukum, Universitas Sumatera Utara, Voulume 25, Universitas Suryakencana, Medan 2013.

Cianjur Jawa Barat, 2017.

Yuli Susanti, "Perlindungan Hukum Bagłlaya Asokawati, "Perlindungan Hukum Pelaku Tindak Pidana Aborsi (Abortus Terhadap Perempuan Korban Provocatus) KOrban Perkosaan", Perkosaan Yang Melakukan Aborsi", Jurnal Ilmu Hukum Syiar Hukum, Universitas Islam Indonesia, Volume XIV, UNISBA, 2012. Yogyakarta, 2017.

Harkristuti Harkrisnowo, "Perempuan Dan HAM Dalam Perspektif Yuridis Dalaw. Negara Dan Kekerasan Terhadap Perempuan", Yayasan JurndRepublik Indonesia, Undang-Undang Nomor Perempuan, Volume II, Jakarta, 2000. 36 Tahun 2009 Tentang Kesehatan

Pulinus Soge, "Legalisasi Aborsi Di Indonesia (Perspektif Perbandingan Hukum Pidana: Antara Common Law dan Civil Law System)", Fakultas Hukum Universitas Atmajaya Yogyakarta, Yogyakarta, 2009.

Jeanet Klara M. Paputungan, "Aborsi Bagi Korban Perkosaan Ditinjau Dari Undang-Undang Nomor 36 Tahun 2009 Tentang Kesehatan", Universitas Sam Ratulangi, Manado, 2017.

Tanti Kirana Utami, "Tanggung Jawab Dokter Dalam Melakukan Aborsi Tanpa Seijin Ibu Mengandung Atau Keluarga Dalam Perspektif Hukum Positif Di Indonesia", Jurnal Hukum Mimbar Justicia, Volume I, Universitas Diponegoro, Semarang.

Aji Mulyana, "Perlindungan Hukum Terhadap Perempuan Dan Anak Akibat Tindak Pidana Abortus Provocatus Criminalis", Volume I, Wawasan Yuridika, Universitas Suryakencana, Cianjur Jawa Barat, 2017. (Lembaran Negara Republik Indonesia Tahun 2009 Nomor 144 dan Tambahan Lembaran Negara Republik Indonesia Tahun 2009 Nomor 5063).

, Undang-Undang Nomor 39 Tahun 1999 Tentang Hak Asasi Manusia (Lembaran Negara Republik Indonesia Tahun 1999 Nomor 165 dan Tambahan Lembaran Negara Republik Indonesia Tahun 1999 Nomor 3886).

, Undang-Undang Nomor 23 Tahun 2003 Tentang Perlindungan Anak (Lembaran Negara Republik Indonesia Tahun 2002 Nomor 109 dan Tambahan Lembaran Negara Republik Indonesia Tahun 2002 Nomor 4235).

-, Peraturan Pemerintah Nomor 61 Tahun 2014 Tentang Kesehatan Reproduksi (Lembaran Negara Republik Indonesia Tahun 2014 Nomor 169 dan Tambahan Lembaran Negara Republik Indonesia Tahun 2014 Nomor 5559). 
